\title{
Open Access Religious Resources for your Students
}

Jeff Siemon, Anderson University

\begin{abstract}
Open Access (OA) journal collections can add diversity and breadth to a library's theological resources. I discussed my experience of creating a collection of over 800 OA religion journals in the OCLC Knowledge Base. For OCLC member libraries, these titles may be added to their library catalog. For other libraries, these titles are available through the Open Access Digital Theological Library. The session touched on OA materials from majority world regions and languages such as Spanish and Korean. The proceedings include a list of OA collections and a bibliography. There was time for questions and sharing experiences.
\end{abstract}

\section{INTRODUCTION}

I'm writing about a new collection of open-access religion e-journals that I compiled and then sharing some of what I learned through making the collection. I'm grateful to be part of Atla and learning with and sharing with colleagues at this session. Before this year's conference went virtual, Atla members were going to gather in Dallas/Fort Worth; twenty-nine years ago, I attended my first Atla conference in Fort Worth. Many colleagues gathered for this session, expressing their interest in open-access religion journals.

As attendees gathered they built a "word cloud." "What words come to mind when you hear 'Open Access Religion Journals'?” 
WORD CLOUD: What words come to mind when you hear "Open Access

Religion Journals"?

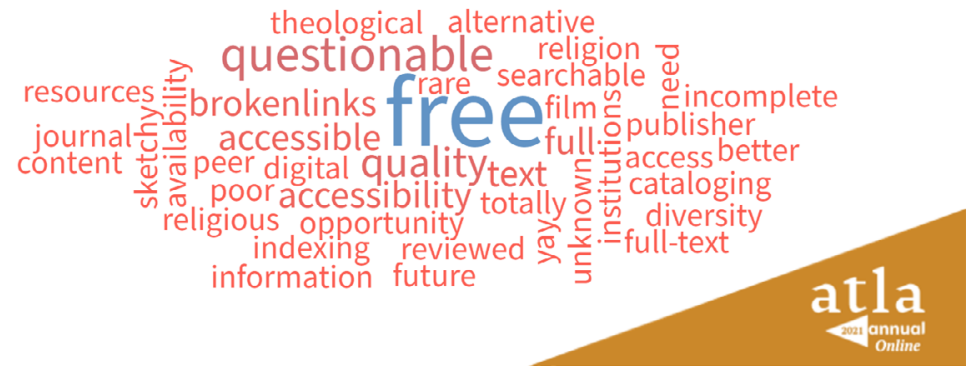

\section{INTRODUCING THE COLLECTION}

I've been working on an OCLC Knowledge Base collection: "Open Access Religion Journals.” I made it for my library and to share with other libraries. I gathered over $800 \mathrm{OA}$ e-journals in the field of religion, theology, philosophy, and ethics.

I think this OA religion journals collection will be helpful to libraries that subscribe to "Atla Religion Database." It will mesh well with the Atla indexing. I encourage libraries to select this collection.

The collection name is Open Access Religion Journals. WMS KB collection ID is global.930.101. The collection is available through the OCLC Collection Manager, and libraries may add it to their catalog or discovery layer, if they choose. I've presented at past Atla conferences about how to add OA collections from the OCLC Knowledge Base to local library catalogs. Atla member institutions likely have a cataloger, or electronic resource or tech staff who know how to add OCLC KB collections.

During the questions and answer period, an attendee suggested that these journals could be made available through the Open Access Digital Theological Library (https://oadtl.org/). I contacted Tom Phillips, and now the OADTL has included the Open Access Religion Journals collection.

In this presentation, I'm focusing on the content of the collection. 


\section{ADVANTAGES OF SELECTING THIS COLLECTION}

Let me suggest some of the advantages of selecting the Open Access Religion Journals collection. While working on the collection, I found over 800 OA religion e-journals, and I will be adding more journals throughout this summer. It is likely that not many of these religion titles are held in any full-text form by Atla member libraries.

\section{Journals Indexed by Atla or Not Indexed}

Here are some stats. Over 390 of the journals are not found in Atla products. Indeed, many are not found in any OCLC Knowledge Base collection. Tens of these journals did not even have a MARC record in WorldCat. They required original cataloging. One might say that many were somewhat "undiscovered" OA journals.

On the flip side, there are advantages to selecting journals which are well known and indexed in Atla. This collection includes almost 405+ OA journals which are indexed in the Atla collections. Both Atla collections with full-text (the regular and the plus versions) include indexing for all these 405+ OA journals.

Indexing is important. Indexing means that theology and religion students can discover citations for articles in these OA journals. Some of the titles are only indexed, that is Atla does not provide the full-text. Adding the full-text to a library catalog will help a student's discovery-delivery need by delivering the full-text.

Neither Atla product includes full-text for all the OA journals they index. The regular product includes some of the OA full-text. The "Serials Plus" product includes more OA full-text. But neither includes all of the full-text for all of the OA titles that Atla indexes. The new Open Access Religion Journals collection does.

\section{Linking to Publishers' Sites}

Here's another advantage of selecting this OA journal collection. The journal-links go to the original publishers' sites. Often the original publisher sites have older volumes than Atla-sometimes going back decades. And the newest issues are often released on the publisher site before the new issues are loaded by EBSCO.

To give the Atla products their due, there are advantages of Atla including OA full-text. Atla has some open access full-text in their products. Here are two advantages when OA text is integrated into Atla Religion Databases. First, as I worked on the collection, I discov- 
ered that a handful of the indexed OA journals have ceased publication and are no longer available OA on the web. Thus Atla, in a sense, has preserved these ceased OA journals.

Second, the full-text integrated into the indexing may be easier for patrons. Depending upon each library's URL resolver, it may take extra clicks for patrons to get to the full text that is not integrated into the Atla product.

\section{THE EXPERIENCE OF COMPILING THE OPEN ACCESS RELIGION JOURNALS COLLECTION}

Next, I want to share some of what I learned while creating this collection.

\section{Multiple Skills Needed}

I brought to this project wide-ranging background and experience with multiple job responsibilities over my career. I've worked in library areas that some larger libraries separate into different departments. It was an advantage to have skills which cross over different library departments. I made my way as a librarian starting as a cataloger and then moving toward being an electronic resources librarian. Where I currently serve at Anderson University, in addition to electronic resources librarian responsibilities, I spend about a third of my time doing reference and instruction, and I'm responsible for collection development for the School of Theology.

At the reference desk, I've been able to hear students' needs. With collection development, I have the freedom and responsibility to add resources. And as electronic resources librarian, I have the tech skills to find, catalog, and build a KB collection of OA resources. At a larger university, these varied tasks would require cooperation from a team of librarians, likely across departments. By crossing over traditional "silos" of responsibilities, I’ve learned small can be an advantage.

\section{Combining Big Picture and Details in Addressing Open Access}

Another learning from this project was the advantage of combining details with big-picture ideas. I like details as well as big-picture ideas. I've followed open access. I've read articles. I've attended and presented at conference sessions. And I got tired of the big-idea librarians imagining open-access this and open-access that in their 
publishing and blogging and presenting. I decided that I needed to slog into the details. What could be done, and what was possible at this time, for smaller libraries? That's why I pursued this project to make a useful collection of OA religion journals. I learned that it helps that I like details, as well as big-picture ideas.

\section{Need for MARC Records for Open Access}

Now back to what I've learned as I've compiled the OA Religion Journals collection. I was surprised to learn how many OA resources lack MARC records in WorldCat. Over the past 24 months, I've added 163 original MARC records to WorldCat for OA resources. I guess that commercial publishers add records for subscription journals, and libraries add records when they subscribe. It seems that cataloging is sometimes skipped for OA resources. Even if the electronic resources librarian adds OA resources, sometimes the cataloging librarian doesn't get notified that a MARC record is needed. Perhaps the journal needs original cataloging, or the existing record needs to be reviewed and perhaps improved.

I didn't just need to create an open-access collection; I needed to create MARC records for individual titles.

Sometimes I had a print journal MARC record to work from. Here's a tip: OCLC Record Manager has a very useful advanced action to derive an e-resource record from a print record. Some journals didn't have any MARC record. The journals without MARC records tended to be journals published by universities in Latin America, Eastern Europe, or South Korea. With all our talk about commitment to global diversity, open-access U.S., Canadian, and Western European publications were much more likely to have high-quality MARC records.

\section{Open Access Journals Add Cultural Diversity to Library Collections}

I learned, or was reminded again, that OA journals promote diversity, with little cost. The faculty members of the AU School of Theology and Christian Ministries want greater diversity in the library's resources. Wanting diverse library resources is likely a goal at most of our institutions. I learned that many universities in majorityworld countries are ahead of "Western" universities and seminaries in offering their scholarship without cost to the reader. That is, many majority-world universities are publishing open-access journals. It's good to see majority-world universities leading the way. Plus, I've 
been able to address my own institution's desire for greater global diversity in our religion collection through adding OA journals.

\section{Open Access Journals Can Demonstrate Library Value to}

\section{Administrators}

Here's an interaction with school administrators that surprised me. Narratives catch the attention of administrators.

I had thought that OER had a more memorable story than OA journals. OER is Open Education Resources and often refers to free online textbooks or course readings. OER has a simple and compelling narrative. Students don't like expensive textbooks; when librarians advocate for and facilitate OER for faculty and courses, students save money; that makes students happy. That's a compelling narrative and catches the attention of administrators.

Before this project, I fretted that, compared to OER, OA journals and OA e-books had a much less compelling narrative. Few students, or administrators, understand the cost of libraries, especially the cost of e-resources. Library e-resources seem "free" to students already.

Here's my OA journals narrative: A few month ago, my library director got a phone call from the provost. The provost was looking at graphs comparing Anderson University with "peer" institutions. The provost wanted to know why the library was "buying" so many more e-journals compared with our peers. My director checked with me for confirmation, though she knew the answer already - actually Anderson was spending less on e-journal subscriptions than all of our peers, but Anderson had access to more e-journals-thousands more e-journals through open access. Anderson library had diligently selected thousands of open-access journals-not just any OA journals, but academic OA journals for the various disciplines Anderson teaches. The library director could claim two wins compared to our peer institutions: lower subscription costs and more journals for students. The provost was satisfied, maybe even impressed.

\section{SELECTING THE OA JOURNALS}

During the discussion period, attendees asked, "What criteria did you use for selecting these journals?" 
Followed Atla in Subject, Geographic Breadth, and Languages

Regarding disciplines and languages, I tried to follow the lead of the Atla databases. Currently, Atla has a subject priority of expanding its coverage to religion journals, beyond its former traditionally Christian scope. Also, Atla has a language priority of adding religion journals in languages beyond English and Western European languages, and seems to prioritize Spanish and Korean. Along with languages, Atla has been expanding its geographic breadth. Atla's indexed journals reflect these newer three priorities, yet still included are many journals with articles in English and from a Christian tradition. Atla has included periodicals produced by member libraries and institutions, which include academic articles, but which may not have peer review. I tried to follow similar criteria.

Regarding religions, the Open Access Religion Journals collection includes Protestant, Catholic, and Orthodox Christianity, as well as Islam, Hinduism, Baha'i, Buddhism, and some sociological, scholarly study of religion.

Regarding language, the new Open Access Religion Journals collection includes 50+ journals with Spanish-language articles and $20+$ journals with Korean-language articles. Other journals are primarily written in Portuguese, Chinese, Turkish, Arabic, and Eastern European languages. Many include English abstracts. Some publish in multiple languages, often including English or full English translation of articles.

The librarian in me always supports exposing students to global points of view. And some students will appreciate finding journal articles in languages with which they are familiar. But other students will not be able to read some of these languages and will be frustrated that these titles "clutter" their search results. Particularly curious students will use the English abstracts, and Google Translate, to discover the gist of some articles, and expose themselves to a wider variety of points of view.

\section{Indexing as a Selection Criterion}

Indexing is important, so students can find articles. Students need both discovery and delivery. As I wrote above, I included all OA journals indexed in Atla RDB. Of those journals not indexed by Atla, many of the articles are cited (author and title) in WorldCat.org Discovery. 


\section{Academic Quality}

I focused on journals associated with universities, seminaries, or academic societies, and with peer review-or at least editorial review. I included some journals without peer review, though published by academic institutions. Often these non-peer-reviewed journals publish articles primarily by the faculty from the publishing institute, or guest lecturers at that institution.

\section{HOW DID I FIND THESE OA JOURNALS?}

During the discussion period, attendees asked, "How did you find these journals?” The short answer is all sorts of ways.

\section{ILL Requests}

For example, sometimes I substitute for our ILL librarian. If I have time, and Anderson library doesn't own the journal or the volumes, I dig deeper. Some journals archive back issues in the repository of the sponsoring university. Also, some ILL requests I find by searching for the title in a search engine; I then add the journal to this project.

\section{Global OA Projects}

As a more systematic attempt, I subscribe to news releases from global OA projects and aggregators, such as Dial.net, SciELO, CEEOL, African Journals Online, etc. As these projects launch or announce journals, I keep my eye out for religion journals.

SciELO, in particular, is a non-profit for improving the publication of academic journals in Latin American and Africa. Its journals are OA, peer-reviewed, have an independent editorial board of scholars from different institutions, publish regularly, share a common software platform, but are locally managed, and are often indexed in international systems.

\section{Commercial Aggregators}

Aggregators-e.g., ProQuest, de Gruyter, etc.—offer title lists indicating which of their platform journals are OA. Then I find the original publisher websites. Again, often the original publisher's website has deeper and/or newer coverage. 
Find Other Journals on the Same Platform

When I run across one OA journal from a university, I explore their platform for other journals. When I have time, I nose around the university's repository or publications pages. Often, I find other OA journals published by that same university.

\section{Discontinued OA Collections}

Unfortunately, OCLC discontinued several large OA collections in June 2018. There were some licensing issues with the organization which first gathered these OA journal titles. Before OCLC deleted these collections, I downloaded 12,000+ OA journal titles. Many were poor quality, or predatory, or had disappeared from the web. Yet, slowly combing through them I've found academic religion OA journals which were not listed elsewhere.

\section{Applications from Journals to the Directory of Open Access Journals}

And lastly, answering how I find these OA religion journals, I've gone to the DOAJ site (Directory of Open Access Journals). Their site has lists of journals which applied to be included, but haven't met their high bar, or did not reapply. "High quality" for DOAJ means that the journal has applied for inclusion, and:

- primary target audience should be researchers or practitioners

- must have an editor and an editorial board, at least two members have a PhD or equivalent

- all articles must pass through a quality control system (peer review)

- use of a plagiarism checking service is recommended

- must be currently publishing

- must not require users to register to read content

- must reapply at certain intervals

I've been looser than DOAJ, particularly on the last three criteria. I've been willing to include journals which have suspended or ceased publication; sometimes they have merely changed their title. I've included some large sites that require a free registration to view the full text. I've included some journals edited by scholars from a single university or seminary. I've included some journals that were accepted to DOAJ at one time, but neglected to reapply for inclusion. 
Attendees participated in an online poll. The poll question was "What is your library doing with OA journals?" and there were five choices:

a) We do not include OA in our catalog/discovery.

b) We curate individual OA journals using the same standard as subscriptions.

c) We add OA collections from commercial publishers when we already subscribe to some of their journals.

d) We add major OA collections to our catalog/discovery (e.g. DOAJ, SciELO, Dial.net).

e) We actively seek out individual OA journals published by universities and societies.

\section{What is your library doing with OA Journals?}

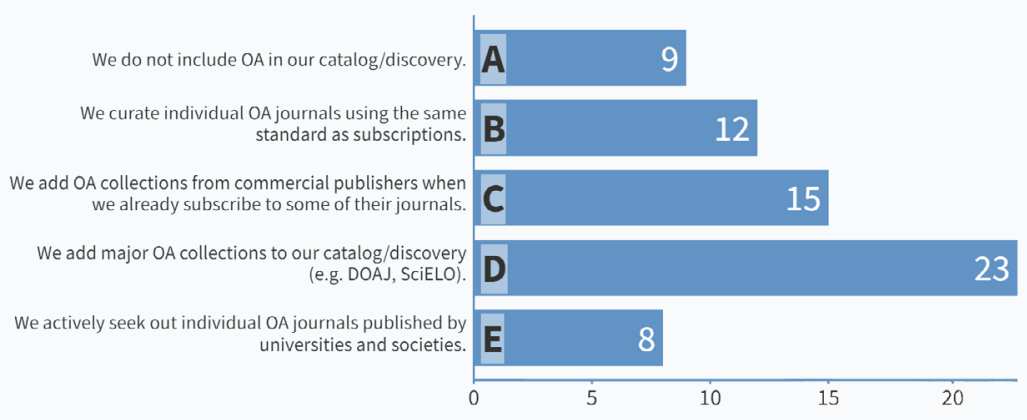

\section{OTHER QUESTIONS AND COMMENTS}

What statistics and analytics are there for open-access religion journals?

For specific universities and seminaries, it is difficult to measure their students' and professors' use of open-access resources. It is a widely discussed and unsolved problem.

For OA journals themselves, there are measures that are becoming increasingly standard. SciELO measures downloads and references by year and country. Their "Human Sciences" and "Linguistics, Letters and Arts" journals average over 1 million article downloads a month over the most recent two years. Articles from those two journal subject categories have been referenced in other scholarly 
journals 1.05 million times over the last five years. In SCImago journal ranking, 699 SciELO journals are listed, 57 journals are in the Q1 (first quartile) for citations with their discipline. SciELO is able to get this data because the journals use a common platform.

Other individual journals have strong analytical measures. Often they use Google Analytics. One OA editor told me that when they moved from a subscription model to an OA model their article downloads increased by a factor of three; also, their articles were getting viewed from more countries. Caraveo and Urbano (2020) published a way for individual journal publishers to use Google Analytics to gather comprehensive stats. Joshua Avery published in Theological Librarianship an article about OA articles from highly ranked religion journals (Avery 2018).

What other open-access journal collections would you recommend?

\section{Directory of Open Access Journals (DOAJ)}

- OCLC Collection ID: DOAJ.Records - URL: http://www.doaj.org/

- Full-text and citation searching of high-quality periodicals, from 125+ countries, 80 languages, 16,147 journals, 5 million+ articles.

\section{SciELO (Latin American and Africa)}

- OCLC Collection IDs by country, such as scielo.argentina URL: https://scielo.org/en

- SciELO include 700+ open access journals from 16 countries. The journals are published by universities, and articles undergo peer review.

\section{Dialnet}

- OCLC Collection ID: openly.jsCate.dialnet URL: https://dialnet. unirioja.es/

- An index database of Spanish and Portuguese language journals, with approximately 20\% OA full-text included in Dialnet, and an additional approximately $25 \%$ with external links to OA. Emphasizes the arts, humanities, and socials sciences. Journals are selected for their academic quality and the willingness of a library to index the articles. 11,000+ journals, 280,000+ Theses; $50,000+$ books (many are books of essays). Free registration required. 


\section{CEEOL}

- OCLC Collection ID: ceeol.oajournals URL: https://www.ceeol. com/

- The Central and Eastern European Online Library includes 2,469 journal titles, 2,050+ are open-access journals. The journals are aggregated from Central and Eastern European universities. Unfortunately, a free registration is required.

Open Access eJournals (McGill)

- OCLC Collection ID global.53639.8.mcgillejournalsopenaccess

- Scholarly OA journals gathered by McGill University libraries. Many are not in DOAJ.

French National Bibliographic Agency of Higher Education collections

- OCLC collection bacon mir@bel: global libreacces OCLC Collection ID: bacon.MIRABELGLOBALLIBRESACCES

- 7,400+ OA serials identified by ABES (Agence bibliographique de l'enseignement supérieur = Bibliographic Agency of Higher Education) for its bacon (BAse de COnnaissance Nationale = National Knowledge Base)

- Also, OCLC supplies open-access ABES collections for individual platforms and publishers.

- These collections seem to have accurate URLs. I don't know the criteria for inclusion.

\section{PLOS (Public Library of Science)}

- OCLC Collection ID allenpress.plos URL: https://plos.org/

- PLOS was a pioneer, and continues to innovate in open access publishing, but only in the sciences.

\section{What open-access e-book collections would you recommend?}

Directory of Open Access Books (European Networks) aka. DOAB

- OCLC collection ID oapen.doabooks URL: https://www.doabooks.org

- 33,800+ e-books, the vast majority from academic publishers and university presses

JSTOR eBooks Open Access

- OCLC collection ID jstor.oaebooks

- 7,100+ OA e-books. Some are not included in DOAB. 


\section{BIBLIOGRAPHY}

Avery, Joshua. 2018. "The Open Access Availability of Articles from Highly Ranked Religious Studies Journals: A Study of Ten Journals.” Theological Librarianship 11:1. https://www.doi. org/10.31046/tl.v11i1.465.

Caraveo, Alex Vitela, and Cristóbal Urbano. 2020. “Analítica Web En Revistes Acadèmiques d'accés Obert: Justiflcació, Planiflcació i Aplicacions.” BiD: textos universitaris de biblioteconomia i documentació, 45. https://doi.com/10.1344/BiD2020.45.14. [published with an English translation at the same DOI]

Chesner, Michelle. 2020. "JS/DH: Primary Sources and Open Data." Judaica Librarianship 21 119-21. https://ajlpublishing.org/index. $\mathrm{php} / \mathrm{jl} /$ issue/archive

Fruin, Christine. 2018. “Open Access: Myths, Facts, Actions.” ATLA Summary of Proceedings 72. https://serials.atla.com/proceedings/ issue/archive.

Greene, J. W. 2017. "Developing COUNTER Standards to Measure the Use of Open Access Resources”. Qualitative and Quantitative Methods in Libraries 6:2. http://www.qqml-journal.net/index.php/ qqml/article/view/410.

MoChridhe, Race. 2019. "Defining Digital Theology: Barthian Reflections on the Role of Open Access and Electronic Publishing in the Theological Toolkit.” [Poster] Atla Summary of Proceedings 73. https://serials.atla.com/proceedings/issue/archive.

Piwowar, H.; Priem, J.; Orr, R. 2019. "The Future of OA: A Large-Scale Analysis Projecting Open Access Publication and Readership”. BioRxiv, preprint no. 795.310. https://doi.org/10.1101/795310.

Pooley, J. "Scholarly Communications Shouldn't Just Be Open, But Non-Profit Too.” LSE impact blog. August 15, 2017 http://blogs.lse. ac.uk/impactofsocialsciences/2017/08/15/scholarly-communications-shouldnt-just-be-open-but-non-profit-too .

Rickards, Lev, and Shannon Kealey. 2020. "The System of Scholarly Communication through the Lens of Jesuit Values.” Journal of Moral Theology 9. http://msmary.edu/College_of_liberal_arts/ department-of-theology/journal-of-moral-theology.html. 
Strinzel, Michaela, Anna Severin, Katrin Milzow, and Matthias Egger. 2019. "Blacklists and Whitelists to Tackle Predatory Publishing: A Cross-Sectional Comparison and Thematic Analysis.” MBio 10:3. https://www.doi.org/10.1128/mBio.00411-19. 